\title{
A comparative analysis of ethical \\ development of student nurses registered for a basic degree and basic diploma programme in KwaZulu Natal
}

\author{
NG Mtshali, Lecturer, University Of Natal \\ T Khanyile, Lecturer, University Of Natal
}

\begin{abstract}
A comparative descriptive study was conducted to establish whether the Comprehensive Basic Nursing Course (CBNC) is able to develop students ethically, and how educational preparation from two different programmes (basic degree and basic diploma) influence their ethical development. This study was conducted because of the concerns on the escalating number of litigations instituted against nurses. Several studies have indicated that some of these litigations are as a result of the growing complexity of the health care system and the society's increasing awareness of their human rights. Some studies have shown that nurses are failing to make principled and ethically sound decisions because they are inadequately prepared to handle ethical issues in an ethically responsible manner.
\end{abstract}

A purposively selected sample of third and fourth year students from both programmes was used. Data was collected from both groups through the use of questionnaires. The findings revealed that the students are developing ethically in a CBNC but the level of ethical development is influenced by their educational preparation, teaching approaches and strategies used, clinical environment, hospital bureaucracy, rules and policies.

\section{Opsomming}

'n Vergelykende beskrywende studie om te bepaal of die Komprehensiewe Basiese Verpleegkunde Kursus (KBVK) studente eties voorberei, en of die onderrig voorbereiding van twee verskillende programme (die basiese graad- en die basiese diploma kursus) die student se etiese ontwikkeling beïnvloed. Hierdie studie is gedoen as gevolg van die stygende aantal gevalle van geregtelike vervolging teen verpleegkundiges. Verskeie studies het aangetoon dat sommige van hierdie geregtelike vervolgings die gevolg van die groeiende kompleksiteit van gesondheidsdienste en die gemeenskap se toenemende bewustheid betreffende menseregte is. Sommige studies het aangetoon dat verpleegkundiges in gebreke bly om beginselvaste en eties suiwer besluite te neem as gevolg van onvoldoende voorbereiding betreffende die verantwoordelike hantering van etiese kwessies.

'n Doelgerigte en uitgesoekte steekproeftrekking van derde- en vierdejaar studente van beide programme is gebruik. ' $n$ Vraelys was benut om die data van beide groepe in te samel. Die bevindinge het aangetoon dat die studente wel etiese vaardighede ontwikkel in ' $\mathrm{n} \mathrm{KBVK}$ maar dat die vlak van etiese ontwikkeling deur die onderrigvoorbereiding, onderrig benaderings en strategieë wat benut word, kliniese omgewing, hospitaal burokrasie, reëls en regulasies beinvloed word.

\section{Introduction}

Nursing programmes worldwide are challenged to produce graduates who will be able to meet the changing needs of the population existing in the post modern era, which is characterized by heterogeneity, difference, fragmentation and indeterminacy. The post modernism era poses the greatest challenge more especially in the democratic South Africa with diverse multi-cultured population, which is literary reflected by eleven languages. Nursing graduates in this country are expected to live up to these diversities by being well prepared in all forms of knowing (personal, aesthetic, ethical and empirical). Their educational preparation should enable them to make sound decisions in their daily practice, of which most of these decisions are ethical in nature. Ethics therefore is vital to nursing as it is perceived as the foundation of committed service to mankind (Pera and van Tonder, 1996).
Kollermoten, Strandberg, and Thomsen (1981) argue that health professionals are generally prepared to function in the scientific realm, whereas clinical decision making demands that they are taught the logical analysis of ethical problems. Dewey (1963) indicated that there is a need to overcome the widening gap between scientific knowledge and morality. He felt that ethics is failing to keep pace with advances in technology and physical science. As a solution to this concern, Reilly and Oermann (1985) contend that moral and ethical development (which is part of the affective domain) needs to be seen as important as the cognitive and psychomotor domains. Rutty (1998) further asserts that "although scientific realm is a necessary, important and critical element of nursing it is important to acknowledge the aesthesic, personal and ethical (own emphasis) knowledge too because all are crucial to nursing practice" 
p 246.

Ethical and legal responsibilities attached to nursing practice cannot be ignored. They pose a challenge to academic nursing programmes. In summary the recommendations from the studies related to the ethical development of nurses included that:

- Academic nursing programs should have ways of assisting nurses to increase their knowledge base regarding ethics and ethical decision making to develop their ability to articulate and defend their decisions.

- Introduction of innovative curricular approaches and teaching strategies.

- $\quad$ Exposure of students to clinical environments with rich and varied learning experience..

- $\quad$ Assigning students higher responsibilities according to their level of training and experience. (Gaul, 1987; Felton and Parsons, 1987, Kyriocos, 1992; De Klerk. 1998).

\section{Problem Statement}

The reviewed literature indicated that there is a limited number of studies done on ethical development of nurses, especially in South Africa. Studies previously done have focused on the qualified nurses' abilities in handling ethical issues, and less attention has been given to the ethical development of the students.

Ntombela, Mzimela, Mhlongo and Mashaba (1996) conducted a study on the clinical performance of graduates from the CBNC. The professional nurses who were participants in this study evaluated the clinical performance of CBNC graduates. The findings indicated that $\mathrm{CBNC}$ graduates' clinical performance in all aspects (including application of nursing ethics to practice) was far below that which was expected. The researcher in the present study decided to evaluate the students themselves to ascertain whether they are developing ethically in the CBNC.

\section{Objectives of the study}

The study was aimed at:

- $\quad$ Establishing whether the four year CBNC does foster ethical development of students.

- Comparing the level of ethical development of diploma and degree students both involved in a four year CBNC.

- $\quad$ Establishing whether there is a relationship between educational preparation and ethical development.

\section{Theoretical Framework}

Due to the complexity of the research study, two frameworks were used to guide the entire process namely; Kohlberg's cognitive theory of moral development (1981) and the International Council of Nurses (ICN) Code for Nurses (1973).

\section{Kohlberg's cognitive theory of moral development}

Kohlberg's theory of cognitive development theory was relevant to the study because it deals with different levels and stages of development hence the researcher aimed at establishing the levels of ethical development of students in a CBNC. The focus of this theory is on the maturation of an individual. Kohlberg (1981) identified three major hierarchical levels of development namely; pre-conventional, conventional and postconventional levels in which an individual progresses from one stage of development to the other until the highest stage of development. Within each level there are two progressive developmental stages reflecting a distinct way in which moral problems can be evaluated see, Figure 1.

\section{The International Council of Nurses Code for Nurses}

The value statements in the ICN Code for Nurses (1973) were used to measure the degree to which the students' practice reflects an ethical behavior. According to Fry (1994) the codes provide an ethical foundation and appropriate content for decision making in nursing practice. Certain nursing values were observed under each value statement, see Table 1.

\section{Methodology}

A comparative descriptive design was used in this study. This design was relevant because comparative descriptive designs are structured to describe and compare differences in variables in two or more groups (Polit and Hungler, 1991). The researcher sought to describe the effectiveness of the CBNC in develop-

\section{Figure1: Summary of Kohlberg's Cognitive Moral Development Model (1978)}

Level I Pre-conventional-Externally established rules determine right or wrong_action

Stage 1 Orientation is to obedience and avoiding punishment

Stage 2 Right action is that which satisfies self

Level II Conventional- Loyalty and conforming to existing social order are considered important

Stage 3 Seeks approval by pleasing others

Stage 4 Law and order and duty orientation

Level III Post-conventional The individual autonomously examines and defines moral values and principles apart from group norms and culture.

Stage 5 The social- contract, legalistic orientation

Stage 6 Moral reasoning is based on principles

Choices involves logical universality 
Table 1: ICN Code for Nurses value statements and nursing values

\begin{tabular}{|c|c|}
\hline ICN Code for Nurses Value Statements & Nursing values \\
\hline Nurses' fourfold responsibility & $\begin{array}{l}\text { Health promotion, illness prevention, restoration of health, alleviation of } \\
\text { suffering, self-determination and autonomy }\end{array}$ \\
\hline Nurses and People & $\begin{array}{l}\text { Respect of patients' values, customs, spiritual beliefs, dignity and } \\
\text { confidentiality }\end{array}$ \\
\hline Nurses and Practice & $\begin{array}{l}\text { Competency, accountability, continuing learning maintenance of } \\
\text { standards of professional conduct }\end{array}$ \\
\hline Nurses and Society & Collaborative action and collaborative work \\
\hline Nurses and Co-workers & Co-operation and collaborative work \\
\hline Nurses and the Profession & $\begin{array}{l}\text { Advocacy, professional competence, licensing, maintenance of professional } \\
\text { standards }\end{array}$ \\
\hline The principle of optimacy & Maintenance of competence in practice \\
\hline
\end{tabular}

ing students ethically, compare their level of development in two different programmes, diploma and degree and how educational preparation influence their ethical development.

A purposively selected sample of third and fourth year diploma and degree students involved in a CBNC was used. The researcher assumed that nursing students at these levels of training had adequate knowledge foundation and clinical experiences in handling ethical issues. All students enrolled in these two programmes volunteered to participate but only eighty-one participants responded.

\section{Data collection instrument}

A three sectioned questionnaire was used for collecting data. Data was collected on demography, application of nursing ethics to practice; and solving and ethical dilemma. An ethical dilemma was extracted from Crishaw (1981) see Appendix 1. The application of nursing ethics theory to practice was based on the ICN Code for Nurses ( 1973) and an ethical dilemma had three subsections which were based on Kohlberg's theory of cognitive moral development. After the careful construction of the instrument, content validity and test retest reliability was done before the administration of the instrument to the participants.

\section{Data collection and analysis}

The questionnaire was distributed to the participants and collected by the researcher. Forty diploma students $(n=49.5 \%)$ and forty-one degree students $(\mathrm{n}=50.5 \%)$ responded. The data was analyzed statistically. Frequency counts were done to analyze the demographic data and cross tabulations using the Chi-square test were performed to test the difference between the responses of the diploma and the degree students and the level of significance was at .05 .

\section{Results}

\section{Application of nursing ethics theory to nursing practice}

Both groups scored relatively high on twenty one (21) out of twenty five (25) items in the application of ethics theory to practice, but differences were noted in their scores. The diploma students scored higher than degree students in eighteen (18) items which evaluated professional practice, patient advocacy, accountability and cooperation. The degree students scored higher than the diploma students in three items which were associated with the clients' right to self-determination, autonomy and maintenance of competence in practice.

The statistical significance was noted only on four (4) items reported in Table 2. The table shows the percentages of the number of students that strongly agreed and agreed to the given statement; the Chi square, the significance level and the degrees of freedom (DF).

\section{Accepting gifts and rewards from patients}

This statement aimed at evaluating the maintenance of standards of professional conduct. By comparison, fifty nine percent $(59 \%)$ of degree students and thirty percent $(30 \%)$ of diploma students agreed strongly to this statement. The difference was statistically significant at .02 level and the chi square 11.0. The higher percentage of degree students agreed to this statement.

\section{Practicing after removal from the register}

The values of interest which were attached to this statements were commitment to the nursing profession, maintenance of professional standards and the duty to maintain registration. By comparison seventy one percent $(71 \%)$ of degree students 


\begin{tabular}{|l|l|l|l|l|c|}
\hline \multirow{2}{*}{ Item } & \multicolumn{2}{|c|}{ Agree/ Strongly Agree } & \multirow{2}{*}{ Chi-square } & \multirow{2}{*}{ Significance } & \multirow{2}{*}{ DF } \\
\cline { 2 - 5 } & Diploma \% & Degree\% & & & \\
\hline Accepting gifts/rewards from patients & $30 \%$ & $59 \%$ & 11 & 0.02 & 4 \\
\hline $\begin{array}{l}\text { Practicing after name removal from the } \\
\text { SANC register. }\end{array}$ & $40 \%$ & $71 \%$ & 12.5 & 0.02 & 5 \\
\hline $\begin{array}{l}\text { Nurses advertising medical products } \\
\text { Ignore confidentiality in HIV/AIDS clients }\end{array}$ & $33 \%$ & $71 \%$ & 15.8 & 0.03 & 4 \\
\hline
\end{tabular}

and forty percent $(40 \%)$ of diploma students agreed and strongly agreed to practicing without licensing.

\section{Advertising medical products}

The fundamental concept behind this statement was the nurse as the patient and public's advocate. About seventy one percent $(71 \%)$ of degree students and thirty three percent $(33 \%)$ of diploma students indicated that nurses can advertise medical products. The level of significance was .03 and the Chi-square was 15.8 .

\section{Confidentiality and clients or patients living with HIV/AIDS}

Concerning the rights of clients/ patients living with HIV/AIDS to confidentiality, about thirty three percent $(33 \%)$ of diploma students and $24 \%$ of degree students agreed and strongly agreed to ignoring this right. The level of significance was .02 and the Chi-square 11.4

\section{Level of ethical development in handling an ethical dilemma}

The level of ethical developments was established through evaluating the student' autonomy in decision making, principled thinking and familiarity with ethical dilemmas, and the following results were obtained:

\section{Autonomy in decision making in an ethical dilemma}

In the ethical dilemma that was used, the participants had to make a decision on whether to answer the questions of a dying cancer patient or to respect the wishes of the family as ordered by the physician, by keeping the information from the patient. This was aimed at evaluating the student's autonomy in handling ethical dilemmas in their practice. Table 3 has the summary of these results.

Seventy five percent $(75 \%)$ of diploma students and eighty percent $(80 \%)$ of degree students chose to respond to patient's question and ten percent $(10 \%)$ of diploma students and eighteen percent (18\%) of degree students could not decide what to do in such a situation. Ten percent $(10 \%)$ of diploma students and two (2\%) of degree students felt that the nurse should not answer the patient.

\section{Principled thinking}

The participants were given items to rank according to their importance when handling an ethical dilemma, see Table 4.

The level of ethical development was interpreted according to the ranking of items in terms of their importance when handling an ethical dilemma. The reported results are only on the two items, the most important and the least important considerations when handling an ethical dilemma and the results on how the responses were spread throughout the six considerations when handling an ethical dilemma are not reported. According to Kohlberg (1981), the item ranked as the most important consideration is considered the highest level of thinking of that individual and the item ranked the least important consideration as the lowest level of thinking.

\section{The most important consideration when handling an ethical dilemma}

The highest concentration (32\%) of diploma students selected item 2 as their most important consideration when handling an ethical dilemma. The decision on how to handle the dilemma depended on the presence of a physician in the unit. According to Kohlberg (1981) item 2 indicates a low level of thinking in making moral judgements, where one cannot act or make decisions without consulting others. 
Table 4: Frequency scores of ranked items indicating stage of thinking in moral judgement development

\begin{tabular}{|c|c|c|c|c|c|c|}
\hline \multirow{2}{*}{$\begin{array}{l}\text { Considerations } \\
\text { according to importance }\end{array}$} & \multicolumn{3}{|c|}{ Diploma } & \multicolumn{3}{|c|}{ Degree } \\
\hline & Item & Frequency & Stages & Item & Frequency & Stages \\
\hline $1^{\text {st }}$ most important & 2 & $13(32 \%)$ & $\begin{array}{l}\text { Practical } \\
\text { considerations }\end{array}$ & 1 & $17(42 \%)$ & 4 \\
\hline 2nd & 5 & $14(35 \%)$ & 1 & 3 & $12(29 \%)$ & 2 \\
\hline $3^{\text {rd }}$ & 4 & $13(33 \%)$ & 3 & 4 & $12(29 \%)$ & 3 \\
\hline $4^{\text {th }}$ & 3 & $11(28 \%)$ & 2 & 3 & $10(24 \%)$ & 2 \\
\hline $5^{\text {th }}$ & 6 & $26(65 \%)$ & $5 \& 6$ & 6 & $17(42 \%)$ & $5 \& 6$ \\
\hline 6 th (Least important) & 1 & $21(53 \%)$ & 4 & 2 & $19(46 \%)$ & $\begin{array}{l}\text { Practical } \\
\text { considerations }\end{array}$ \\
\hline \multicolumn{7}{|c|}{$\begin{array}{l}\text { Item } \mathbf{6}=\text { Nursing principled thinking representing Stage } 5 \text { and } 6 \\
\text { Item } 5=\text { Represents Stage } 1 \text { thinking } \\
\text { Item } 4=\text { Represents Stage } 3 \text { thinking } \\
\text { Item } 3=\text { Represents Stage } 2 \text { : thinking } \\
\text { Item } 2=\text { Practical considerations "low level of thinking" } \\
\text { Item } 1=\text { Represents Stage } 4 \text { thinking } \\
\text { Source: Rest } 1979 \text { cited in Crishaw } 1981: 107\end{array}$} \\
\hline
\end{tabular}

The most important consideration for the highest number (42\%) of the degree students was item 1, "how I can best follow the specifications on sharing information on the patients Bill of Rights". According to Kohlberg (1981) considering the patients Bill of Rights before making decisions represents level four of thinking. Individuals at this level see everyone in the society as having a right to be protected by law.

\section{The least important consideration when handling an ethical dilemma}

The highest percentage (53\%) of diploma students considered item 1 "how I can best follow the specifications on sharing information on the patients Bill of Rights", as the least important consideration when handling an ethical dilemma. The degree students $(46 \%)$ considered item 2, "practical considerations in handling ethical dilemmas" as the least important.

\section{Familiarity with an ethical dilemma}

The participants had to indicate how familiar they were with an ethical dilemma. Sixty-nine percent $(69 \%)$ of degree students and twenty-five percent ( $25 \%$ ) of diploma students were familiar with an ethical dilemma, and whether they previously had an opportunity to make a decision in an ethical dilemma. Thirty seven percent $37 \%$ of degree students and sixty-eight $(68 \%)$ of diploma students were not familiar with the ethical dilemma but the dilemma that was presented was conceivable to them. To five percent $(5 \%)$ of diploma students the ethical dilemma seemed remote and unreal.

\section{Discussion}

Although the results were inconclusive because of the sample size, the results on the application of nursing ethics to practice indicated that nursing students in the CBNC are developing ethically although their level of development, and the areas of development are not the same. The findings also indicated that education preparation plays an important part in the students ethical development.

\section{The influence of educational preparation in ethical development}

The higher scores of diploma students in the application of ethics theory to practice supported the reported findings by Yung (1997) and Crishaw (1981). These findings suggested that exposure in the wards environment facilitates the ability to apply ethics theory to practice, and that clinical experiences challenges the students' ethical development. The students in a diploma programme were based in hospital throughout their course and therefore had more time in the ward environment. The degree students were involved in a Community Based programme which required them to spend time in the community and a certain portion of time in ward environment. Because of the limited time spend by the degree students in ward environment, they had less exposure to practice applying ethics theory to their practice in ward environment, where professional nurses role model and assist them in their ethical development as professional nurses. In the community the degree students were working in multidisciplinary and multi-sectoral teams. Professionals from these teams served as their role mod- 
els and influenced their development in working collaboratively with others.

In addition to these findings, degree students were prepared using a Problem Based approach and diploma students were prepared through a conventional method. Studies have shown that conventional methods covers more content, whereas problem based learning enhances more depth coverage than breath (Coulson and Osborne in Albanese and Mitchell, 1993). The diploma students covered more ethics theory (the breadth) in their programme whereas degree students covered more depth. The ethics content covered in degree programme was based on the existing ethical problems identified in the clinical settings. They focused more on what was relevant at that time. This accounts for diploma students scoring higher than degree students in the application of ethics theory to practice.

The degree students scored higher than diploma students on issues of patients' rights to self-determination and autonomy because of their socialization. The degree students in their programme are socialized to place greater value on professional autonomy. The degree students are developed to view themselves as autonomous beings with freedom to approach the lines of communication in the ward environment, ask questions and free to make suggestions. In their programme, partnerships with patients in patient care is emphasized and clients are regarded as autonomous beings with rights to make their own decisions under the guidance of the health professional. These findings were confirmed by de Jong in Yung (1998).

The degree students scored higher in the maintenance of competence in their practice. In the Community Based/ Problem Based programme the students are developed in a way that enables them to continue to learn throughout their work experience. Developing the students to be lifelong learners assists in maintaining and improving their personal competence, and this may account for their high score in maintenance of competence.

\section{Autonomy in the clinical environment}

A high level of autonomy is a necessary prerequisite for appropriate confrontation of ethical issues and dilemmas and for upholding ethical standards of practice, since nurses function in complex and difficult nursing environments. Due to the nature of the work done by nurses, (caring for vulnerable individuals, working with colleagues and other professionals who may have conflicting opinions, and working in institutions with their own vested interests) to work as patients advocates they need to be able to stand for what is morally or ethically accepted, as indicated by Cassidy and Oddi (1988).

The findings suggested that the students in both groups have developed to a certain level, the ability to make decisions on their own, but the degree student scored higher than the diploma students. This is because of their community based experiences. Community based experiences facilitates self direction, autonomy and independence. The community exposure fosters critical thinking, problem solving and autonomy in decision making as they spend most of the time on their own in the community with the facilitator available only when necessary. Bellack (1998) stated that community based experiences provide the students with greater opportunities for autonomy, independence and risk taking and that it develops in them broader competencies which include problem solving. The students in communities get front line experiences which they may not get in hospitals and this may have contributed to degree students scoring higher in autonomy.

\section{Bureaucracy, organizational policies and ethical development}

The socialization of diploma students may have contributed to the majority of the diploma students selecting the item that indicated the lowest level of thinking. According to Yung (1997) college nurses are socialized in an environment where they cannot freely make decisions without consulting the seniors or existing bureaucratic structures. This handicaps them in making decisions when faced with an ethical dilemma because their thinking is moulded into a fixed pattern by the existing structures which must be followed or consulted. Socialization in such an environment may hinder the students' ethical development. Yung (1997); Gaul (1987) and Ketefian (1981) support this finding in their argument that institutional policies hinder the growth of students since they practice in an environment with tight bureaucratic structures, and the students do not get adequate opportunities to take responsibility in decision making.

Medical staff also contributes to the problem of inadequate development in decision making because they are regarded as team leaders with more power and they therefore make most of the decisions sometimes without even consulting other team members (Cassidy and Oddi, 1988). The current health care approach emphasizes a multidisciplinary approach with partnerships in patient care and that includes partnerships in decision making. The doctors should not be regarded as having more power than other team members, but all members should be recognized by the roles they play in providing total patient care.

According to Bellack (1998) community based students are exposed to ethical realities which they may be insulated from in hospital settings. The degree students's exposure to self directed learning and work in the community settings contributes to their growth in decision making. These students in the communities are less encumbered by the complexity and regulations of the hospital policy and they have an opportunity to explore their potential in managing situations (Bellack, 1998). Practicing independently and the lack of close supervision in the community environment gives the students enough time to manipulate ethical dilemmas and make ethically sound decisions freely. The results of the study by Boss (1994) also suggested that community work or exposure helps improve the students' confidence in decision making because of the real life experiences they encounter independently in the absence of their teachers.

These results in this study also indicated that very few students from both groups (diploma and degree) were at the highest level of solving ethical dilemmas of which according to Kyriocus (1995) is common in most programmes. Most of the graduates reach level five and six of development after graduation. Exposure to the clinical environment and less constraints in making decisions after graduation develops the nurses ability in handling ethical dilemmas up to maturity. 


\section{Ethical dilemmas and development of thinking skills}

A higher percentage of degree students were familiar with an ethical dilemma because in their programme they are required to identify ethical dilemmas in the clinical environment and analyze how they were handled using ethics theories and principles. Identifying and solving ethical dilemmas familiarized the degree students with the ethical dilemmas of which according to Crishaw (1981) familiarity with solving ethical dilemma improves critical thinking skills and contributes to higher level of thinking. Familiarity with ethical dilemmas therefore accounted for the higher level of thinking in most degree students.

\section{Recommendations}

The theory of nursing ethics should be introduced early in nursing programmes to promote the correlation of ethics theory/ content to daily nursing practice in the clinical environment. In partnership with the college, the staff in the clinical learning environment should draw the students' attention to ethical issues to make them conscious of these issues and how they can apply theory in dealing with them.

Clinical supervision may facilitate ethical development of students by encouraging the students to reflect on their experiences related to handling ethical issues in the clinical settings, because reflecting facilitates academic and emotional growth and development as stated in Boud, Keogh and Walker (1985). The students should also reflect on their experiences during class interaction, and in writing. They may reflect in writing through reflective learning diaries and assignments based on real life ethical dilemmas encountered in the clinical situation. In their reflection they should clearly indicate what they have learned as a sign of growth in handling ethical issues.

The members of the multidisciplinary team, especially the ward sisters, should be approachable for the students to be able to feel free to make inquiries and reflect on the ethical issues identified in the learning environment. The college staff, facilitators and the ward staff should give the students opportunities to make decisions in ethical dilemmas, under their direction. This will help students to develop their analytical thinking and problem solving skills.

The bureaucratic structures in the hospital settings may frustrate the degree students who are used to be independent and autonomous in the community settings. Their autonomy may create some friction between them and staff in the clinical environment. These students need to be prepared for that paradigm shift by their facilitators. In the ward environment the students from Community Based programmes should be given good orientation to existing hierarchical structures or channels of communications, hospital and ward policies, and standing orders, to be accessible to all if there is a need for them to be consulted before making a decision.

Partnerships should also be encouraged between nursing schools and the health service. This will make it possible to update service personnel on the new developments on the teaching strategies and this could be done through in-service training of ward personnel. This may prove to be helpful to the students' development because they are with the ward personnel most of the time. For the ward sisters to be of assistance in guiding and directing the students in the clinical environment, they need to have a better understanding of the learning approaches used in the teaching of students.

When using teaching approaches such as a problem based approach, that do not cover adequate content, other approaches may be used. A case study approach is one approach that may be used to ensure adequate content coverage while at the same time developing the problems solving and critical thinking skills. Cases used may be developed in such that important aspects necessary for ethical development of students are covered.

In the programmes where ethics is integrated in other courses, it is more likely that it is not taught at all, or the teaching may be inconsistent or it may not be explored deep enough, if the teachers have inadequate preparation in nursing ethics as stated in Aroskar and Veatch (1977). To counteract this problem, the educators need to be in-serviced or updated on new developments in the teaching of nursing ethics.

\section{Conclusion}

Nurses play a vital role as advocates and protectors of the client's autonomy, therefore nursing programmes should adequately prepare them to fulfil this ethical responsibility. They should be prepared in such a way that will make them conscious of ethical issues in their daily practice, and the acceptable ways of handling them, despite the pressures surrounding them. Nursing programmes should facilitate the development of analytical, problem solving and decision making skills which are necessary for handling ethical issues. They should learn to reflect on their experiences to facilitate their process of growth. The adequate preparation of students ethically will equip them for meeting the needs and challenges of the multicultured and multi-lingual society in South Africa.

\section{Bibliography}

AROSKAR, M \& VEATCH, RM 1977: Ethics in the curriculum. Nursing Outlook. 25, (4): 260-264.

BELLACK, JP 1998: Community nursing practice: Necessary but not sufficient. Journal of Nursing Education. 37: 99100

BOSS, JA 1994: The effect of community service work on the moral development of college ethics students. Journal of Moral Education. 23, (2): 83-197.

BOUD, D; KEOGH, R \& WALKER, D 1985: Reflection: Turning experience into learning. London: Kegon Page.

CASSIDY, VR \& ODDI, LF 1988: Professional autonomy and ethical decision making among graduate and undergraduate nursing majors. Journal of Nursing Education. 27, (9): 405 410 .

CRISHAW, P 1981: Measuring moral judgements in nursing dilemmas. Nursing Research. 30. (2): 104-110. 
COULSON, RL IN ALBANESE, MA \& MITCHELL, S 1993:

Problem based learning: A review of literature on its outcomes and implementation issues. Academic Medicine. 68, (1): 52-81.

DE KLERK, J 1998: A reappraisal of character education in a progressive postmodernist era. South African Journal for education. 18, (1): 19-23.

DEWEY, J 1963: Philosophy and civilization. New York: Capricorn Book.

FELTON, GM \& PARSONS, MA 1987: The impact of nursing education on ethical/moral decision making. Journal of Nursing Education. 26. (1): 7-11.

FRY, ST 1994: Ethics in nursing practice: A guide to ethical decision making. Geneva: International Council of Nurses.

GAUL, AL 1987: The effect of a course in nursing ethics on the relationship between ethical choice and ethical action in Baccalaureate nursing students. Journal of Nursing Education. 26, (3): 113-117.

INTERNATIONAL COUNCIL OF NURSES. 1973: Code for Nurses: Ethical concepts applied to nursing. Geneva, Switzerland: ICN.

KETEFIAN, S 1981: Critical thinking, educational preparation. and development of moral judgement among selected groups of practicing nurses. Nursing Research. 30, (2): 98-103

KYRIACOS, U 1995: Developing nurses' moral reasoning skills. Curationis. 18, (4): 38-41

KOHLBERG, L 1981: The philosophy of moral judgement, San Francisco: Harper \& Row.

KOLLENMORTEN, I; STRANDBERG, C; THOMPSON, BM ET AL 1981: Ethical aspects of clinical decision-making. Journal of Moral Ethics. 7: 67-69.

NTOMBELA, BB; MZIMELA, ND; MHLONGO, CS \& MASHABA, TG 1996: A study of clinical performance of nurses who recently completed the Comprehensive Basic Nursing Course. Curationis. 19, (4): 13-18.

O'ROURKE VITO, K 1983: Moral development considerations in nursing curricula. Journal of Nursing Education. 22, (3): 108-113.

PERA, SA \& VAN TONDER,S 1996: Ethics in nursing practice. Kenwyn: Juta.

REILLY, DE \& OERMANN, MH 1985: The clinical field: Its use in nursing education. _Norwalk, CT: Appleton- CenturyCrofts.

RUTTY, JE 1998: The nature of philosophy of science, theory and knowledge relating to nursing and professionalism. Journal of Advanced Nursing. 28, (2): 243-250.

SEARLE, C \& PERA,SA 1998: Professional practice: A Southern African Perspective. (3 rd ed.) Johannesburg: Heinemann.
SOUTH AFRICAN NURSING COUNCIL 1985: R.425: Regulations relating to the approval and the minimum requirements for education and training of a nurse (general, psychiatric and community) and midwife leading to registration. Pretoria: SANC.

YUNG, HH 1997: Ethical decision-making and the perceptions of the ward as a learning environment: a comparison between hospital- based and degree-nursing students in Hong Kong. International Journal of Nursing Studies. 34, (2): 128136. 


\section{APPENDIX 1}

Please read the story below and respond to the related questions

Following exploratory surgery, a 48-year-old man was diagnosed as having inoperable lung cancer. The physician informed the patient and his family of operative findings shortly after surgery when the patient was fully alert. A few days later the patient repeatedly asked questions about his health. His lack of knowledge about the diagnosis was evident. The family asked that the patient not to be told about his condition. The physician decided to respect the family's request and wrote an order not to discuss the diagnosis with the patient. The nurse wondered whether to respect the wishes of the family and the physician or to answer the patient's questions.

A. What should the nurse do? Choose one response.

1. Should answer the patient's questions

2. Can't decide

3. Should not answer the patient's questions.

B. The nurse considers the following six issues:

How can I best follow the specifications on sharing information in the patient's Bill of rights?

Is the physician in the unit during the times when it would be possible to discuss this?

Are the wishes of the patient's family most important because the family is closest to the patient?

Would I be meeting the fair expectations of the patient and the family?

Could the family and physician do anything to me for answering the patient's questions?

Does the patient in this case have the right to decide about who should know the diagnosis?

From the list of considerations above, select the one that is most important. Put the number of the most important consideration on the top left line below. Do likewise for your $2 \mathrm{nd}, 3 \mathrm{rd}, 4$ th, 5 th and 6 th most important considerations. Most Important

Second Most important

Third Most Important

Fourth Most Important

Fifth Most Important

Sixth Most Important

C. Have you encountered the similar dilemma? Indicate your previous degree of involvement with a similar dilemma using one of the following choices.

Made a decision in a similar dilemma.

Knew someone else in a similar dilemma.

Not known anyone in a similar dilemma, but dilemma is conceivable.

Difficult to imagine the dilemma as it seems remote.

Difficult to take the dilemma seriously as it seems unreal

Circle one response 1

$2-3$ 4 $-5$

Source: Crishaw, P. 1981. 